Escravidão do corpo e da alma 


\title{
A escravidão nos sermões do Padre Antonio Vieira
}

\author{
ALCIR PÉCORA I
}

$\mathrm{E}$ M VÁRIOS trabalhos relativamente conhecidos, escrevi sobre o tema da escravidão do índio, tal como tratado pelo jesuíta Antonio Vieira (16081697). Nada tenho de novo a dizer sobre o assunto. O que vou fazer aqui é apenas um resumo do que pensei ao longo do tempo, procurando agrupar os diferentes estudos em torno de cinco tópicos-chave, a saber: a adesão aos termos da Segunda Escolástica; o processo de incorporação do indígena ao corpo místico do Estado; os termos usados pelas autoridades portuguesas para definir a missão atribuída a Portugal no Novo Mundo; a natureza indissolúvel do nexo entre conveniência e consciência suposto no chamado antimaquiavelismo; e, por fim, as práticas de conversão adotadas pelos jesuítas no Brasil.

Peço-lhes paciência, portanto.

\section{I}

Começando pelo primeiro ponto, é preciso deixar claro que, muito do que se tem atribuído a uma visão de Vieira sobre o índio é apenas uma retomada de questões já consideradas no âmbito da chamada Segunda Escolástica do século anterior. Um exemplo dessa retomada é a glosa que Vieira faz do tema da obrigação evangélica de "pregar a toda criatura", em contrapartida às teses que negavam estender a fé ao índio sob a alegação de sua pouca inteligência e capacidade espiritual. Para Vieira, como para os escolásticos, o esforço da conversão é dever religioso inalienável do conhecimento dos novos povos, seja qual for o seu grau de polícia ou razão. O indígena está incluído na lei natural implantada no homem por Deus, que o cria capaz de pertencer ao grêmio da Igreja, submeter-se ao Império de Cristo e alcançar a Bem-Aventurança.

A pertença à Igreja se define, por sua vez, no interior de várias condições: primeira, a de que não pode ser entendida fora da relação hierárquica que ordena o Estado católico; segunda, a de que existe um conjunto de direitos adquiridos nesse ingresso, que os colonizadores portugueses têm de reconhecer; terceira, a de que existe um direito natural a ser reconhecido pelos índios - o diveito missionário, deduzido do mandado divino de pregação a toda criatura -, o qual, contrariado, pode dar justa causa à guerra contra ele.

O dominicano Francisco de Vitoria, no De Indis, afirma que "os cristãos têm o direito de pregar, de anunciar o Evangelho aos bárbaros em todas as regiões". " No De Temperantia especifica que "se a pregação for impedida, os espanhóis podem aceitar ou declarar a guerra, por causa disto, se for necessá- 
rio". ${ }^{2}$ Por outro lado, "se os bárbaros permitirem aos espanhóis a pregação do Evangelho, livre e sem impedimentos, quer aceitem, quer não aceitem a fé, não é lícito fazer-lhes guerra nem ocupar-lhes as terras". ${ }^{3}$ Ou seja, assim como os índios não podem ser excluídos do direito natural e das gentes, tampouco podem, sob pena de guerra justa, impedir a ação missionária, causa última a providenciar a vinda dos cristãos ao Mundo Novo.

Ainda de acordo com a posição defendida pela maioria dos autores da Segunda Escolástica, o Padre Vieira vai supor legítimas certas formas de organização política dos índios, bem como o direito de que mantenham consigo a posse de seus bens. Essa admissão de polícia e propriedade, embora bastante condicionada, bastava para impedir que se tomasse por justa causa de escravidão a recusa das tribos de se mudarem para as missões.

Da mesma maneira, quando Vieira critica o cativeiro com base no argumento de que a condição natural do ser humano, criado por Deus à sua imagem e semelhança, é a de liberdade, ele não faz mais que retomar lugares-comuns escolásticos nos quais a redução do indígena à situação de escravo, agravada pela coação violenta, é crime temporal e espiritual. Apenas a prédica pacífica justifica-se quando não há impedimento do direito missionário. Assim, o tema do "pecado mortal do cativeiro", que celebrizou a Las Casas, tem em Vieira um afincado defensor.

No Sermão da Primeira Dominga da Quaresma, de 1653, Vieira interpela assim o auditório maranhense: "Cristãos, Deus me manda desenganar-vos, e eu vos desengano da parte de Deus. Todos estais em pecado mortal, todos viveis e morreis em estado de condenação, e todos vos ides direitos ao inferno. Já lá estão muitos, e vós também estareis cedo com eles, se não mudardes de vida".

Um aspecto em que Vieira insiste talvez mais que os tratadistas é o relativo aos efeitos desastrosos da manutenção dos cativeiros injustos, tanto para os senhores particulares como para o comum da colônia, que se vê assolada por várias "pragas": "Sabeis quem traz pragas às terras? Cativeiros injustos. Quem trouxe ao Maranhão a praga dos holandeses? Quem trouxe a praga das bexigas? Quem trouxe a fome e a esterilidade? Estes cativeiros". ${ }^{5}$

Em carta dirigida ao rei D. Afonso VI, em 1657, Vieira é duro na responsabilização do soberano diante da prática injusta do cativeiro:

Senhor, os reis são vassalos de Deus, e, se os reis não castigam os seus vassalos, castiga Deus os seus. A causa principal de se não perpetuarem as coroas nas mesmas nações e famílias é a injustiça, ou são as injustiças, como diz a Escritura sagrada; e entre todas as injustiças nenhumas clamam tanto ao céu como as que tiram a liberdade aos que nasceram livres, e as que não pagam o suor aos que trabalham. ${ }^{6}$

E agrava a proposição ao levantar nas Escrituras passagem análoga aos desastres causados pelos cativeiros, dos quais não está imune a descendência real: "Com grande dor e com grande receio de a renovar no ânimo de V.M., digo o 
que agora direi: mas quere Deus que eu o diga. A El-rei Faraó, porque consentiu no seu reino o injusto cativeiro do povo hebreu, deu-lhe Deus grandes castigos, e um deles foi tirar-lhe os primogênitos". ${ }^{7}$ A figura desse castigo fatal aplica-se cruamente ao presente da rainha-mãe, que, em 1653, perdera o filho mais velho, D. Teodósio, e a primeira das filhas, a infanta D. Joana. O jesuíta explica ambas as mortes pelo beneplácito real diante de leis com muitas "larguezas na matéria do cativeiro dos índios".

Também em seguimento aos tratadistas, Vieira vai se manifestar contrário à coação violenta dos índios, que considera não apenas ilegítima, mas ineficaz. Já na Carta Ânua, de 1624, afirmava que os índios ficavam "cativos” do "bom trato e conversação", 8 o que supunha que fossem dotados de entendimento e capacidade de aprendizado da doutrina cristã, ao contrário do que propugnavam as teses conhecidas do teólogo John Major, reapresentadas por Juan de Quevedo e Juan Ginés de Sepúlveda, que aplicavam ao índio o conceito de servo por natureza, utilizado por Aristóteles no Livro Primeiro da Politica (em particular no capítulo quinto, para referir os indivíduos em que predomina a força física sobre o entendimento, engenho deficiente e incapacidade de governar-se $\mathrm{e}^{9}$. Um argumento incomum que Vieira aplica, aqui, é o da semelhança irônica entre os escravos e as mulheres dos seus senhores, lembrando-as, no Sermão da Primeira Oitava da Quaresma, que também às almas do gênero feminino "não faltou quem dissesse que não foram criadas à imagem e semelhança de Deus". ${ }^{10}$

No geral, portanto, me parece correto dizer que Vieira adota a posição dos tratadistas do século XVI que reconhece nos índios plena capacidade de entender a doutrina por seu "bom natural" que os inclina à piedade e ao catecismo. Vieira igualmente reconhecia a existência de "polícia” entre os índios, vale dizer, de um sistema de governo regulado por leis tidas como justas pelo conjunto de seus membros -, o que, pelo direito das gentes, bastava para garantir a jurisdição autônoma de suas aldeias, bem como impedir que fossem subjugados por força com a justificativa de que eram incapazes de governo próprio.

Das muitas provas de que o indígena era dotado do lume da razão com que Deus fez análoga a si toda criatura, Vieira conclui pela injustiça do cativeiro a que vinha sendo submetido. Para ele, D. João IV, para fazer jus a seu título de restaurador da liberdade, tinha de instaurá-la também entre os brasis. Vale dizer: ao rei cabe integrar o indígena ao corpo político do Estado enquanto súdito naturalmente livre, e ainda uma segunda vez liberto pelo nascimento na fé por meio da conversão. Assim, recebidos a doutrina e o mistério dos Sacramentos, o indígena passa a fazer parte do corpo da Igreja. Essa é a única condição - e o meio exclusivo - pelo qual o gentio pode aspirar à bem-aventurança -, o que vale também para os negros de África, cuja vinda ao Brasil significaria, a despeito das misérias e trabalhos, a possibilidade de integrar-se ao corpo da Igreja e tomar a via salvífica oferecida ao homem pela lei da Graça. 
Para Vieira, de resto, a condução do gentio ao corpo místico da Igreja, por meio da prática cristã, do conhecimento da doutrina e da recepção dos sacramentos, representa a mais alta finalidade do descobrimento. Há uma dupla implicação a reconhecer nessa afirmação. De um lado, que a conversão era entendida como possível e necessária, sendo o gentio apto para receber a revelação divina e gozar a bem-aventurança, que apenas lhe era negada pela circunstância da sua ignorância de Deus e do seu estado atual de separação do corpo da Igreja. De outro lado, implica entender que a salvação ao alcance do índio apenas existe em virtude de sua integração ao corpo mistico de Cristo, franqueada pelas práticas do sacerdote. Ou seja, fora da Igreja não há salvação possível para o gentio: "Porque ninguém pode subir ao céu, senão incorporando-se com Cristo, como todos nos incorporamos com ele, e nos fazemos membros do mesmo Cristo por meio da Fé e do Batismo". ${ }^{11}$

Ou seja, que não haja engano: a condenação da coação violenta não significa a aceitação de qualquer relativismo religioso. Vale talvez lembrar aqui a observação de Joseph Höffner, bispo de Münster, de que Cristo "não foi nenhum livre pensador liberal do século XIX a anunciar o Evangelho sem exigência de espécie alguma". ${ }^{12}$ Acrescento que Vieira não foi nenhum teólogo da libertação a fazer revisionismo da história da Igreja e a proclamar contrito o mea culpa do "projeto autoritário" da Cristandade colonial. Trata-se aqui de um "absolutismo do Evangelho", ${ }^{13}$ a impor-se nos limites das virtudes cristãs e dentro da própria comunidade eclesial.

Nessa perspectiva histórica, lembro também que a ortodoxia formulada pelos escolásticos que pensaram a Conquista vai muito mais no sentido de um esforço de ordem interna, a partir da integração do gentio na "comunidade sobrenatural" e na "unidade jurídico-moral" indissociáveis da Igreja ${ }^{14}$ do que no de uma ação bélica contra um corpo estranho ao Orbis Christianus. É uma posição cabalmente distinta daquela adotada, nos séculos anteriores, face ao gentio maometano, quando a questão era vencê-lo ou destruí-lo enquanto ameaça ao corpo universal onde não tinha lugar, e não compeli-lo a entrar neste corpo, cuja universalidade, de certo modo, dependia de seu ingresso. A obrigação da conversão, estranha ao ambiente das Cruzadas e guerras da Reconquista, é uma grande novidade das Descobertas, e, como tal, fenômeno decisivo, "norma nacional e religiosa" 15 a participar da fundação da era moderna. ${ }^{16}$

Ainda outras posições de Vieira são adotadas dos neoescolásticos. Por exemplo, quando ele se opõe à ideia corrente no tempo de que a existência entre os indígenas de práticas contranatura, como a poligamia e o canibalismo, fornecia causa justa de guerra. Para Vieira, tais práticas, conquanto antinaturais, não eram consequências da má disposição inata do indígena, mas dos costumes viciosos que poderiam ser corrigidos pela conversão e o ensino. "Muitos há muito rudes e bárbaros" - escreve Vieira ao Provincial do Brasil, em 54 -, "mas por falta mais de cultura que de natureza". ${ }^{17}$ São gente que "não tem os vícios, 
nem os embaraços de consciência, com que vivem pela maior parte os homens de maior polícia". ${ }^{18}$ Contraposição, aliás, que repõe argumento do padre Manuel da Nóbrega debatido em seu Diálogo sobre a Conversão do Gentio: entre o vil costume dos índios e a vã soberba dos filósofos, maior é o pecado destes, já que "não guardam a lei natural posto que a entendam"19

Práticas do mau costume e "ignorância invencível" - isto é, impossibilidade lógica de os índios conhecerem a doutrina que ainda não lhes havia sido ministrada - são atenuantes (e não o contrário) dos pecados dos índios, que anulam tentativas de caracterizá-los como monstruosos ou desumanos. Sem horror, aliás, conta Vieira que índios das nações que viviam na ilha dos Joanes, ao "tomarem nome", segundo a prática que tinham, quebraram a cabeça de treze padres, e, "depois de mortos os assaram e comeram como costumam" ${ }^{20}$ Não é nenhuma idiossincrasia da lábia vieiriana: a maioria dos tratadistas neotomistas já tinha aplicado o argumento da "ignorância invencível", cuja finalidade é atenuar o crime pelo peso do costume e impedi-lo de caracterizar-se com uma deformação inata irreversível.

Vieira inscreve-se, portanto, no quadro de um pensamento que, em meados do século XVII, já não é novidade no seio da Igreja Católica. Não é o caso de se aplicar qualquer termo iluminista (ou pré-iluminista) a ele, pois nem ele é "avançado" em relação ao seu tempo, nem busca qualquer finalidade contestatória ou transgressiva em relação à instituição eclesial. Ao contrário, o lugar-chave da sua atuação é o incremento das missões jesuíticas como condição do êxito tanto da ação espiritual da Igreja como do fortalecimento temporal do Estado português. Esse foi o emprego particular que deu às posições da Segunda Escolásti$\mathrm{ca}$, as quais, originariamente, visavam balizar a ética da Conquista espanhola, nos termos de uma "consciência cristã" -, portanto de um irredutível religioso ${ }^{21}-, \mathrm{e}$ de uma codificação jurídica assentada no Direito natural. São posições modernas que se opunham tanto à antiga mentalidade imperial, que propunha uma ordem política superior aos Estados nacionais, como ao sentimento curialista de uma teocracia submetida temporal e espiritualmente, ao papa. ${ }^{22}$ Em Vieira, dá-se o mesmo, apenas com o acento deslocado da Espanha para Portugal, e com grande reforço do papel missionário da Companhia no cumprimento do plano salvífico da Providência a atuar na história humana e nas almas individuais dos homens.

A lição vieiriana a tirar dos trabalhos dos missionários, assim como da mortandade maciça dos indígenas, nada tem de consciência laica ou ilustrada, mas sim de interpretação providencial da história. Desígnios providenciais levavam os missionários ao Brasil em busca da salvação de almas, a despeito de que ela se fizesse à custa de imensas mortes provocadas pelo contato com as armas e doenças dos europeus. A rigor, para ele, até essas mortes eram abençoadas, se havia tempo para que fossem ministrados os Sacramentos: “[...] Destes [índios enfermos]foram alguns tão venturosos que, sendo tapuias pagãos, acabando de receber o batismo morreram logo, com evidentes sinais de predestinação". ${ }^{23}$ 
O segundo ponto importante a propósito da visão vieiriana da escravidão refere as obrigações dos escravos - negros ou índios - dentro do corpo místico ao qual passam a pertencer e a responder jurídica, política e moralmente. Acima de tudo, respondem à religião que os acolhe na fé verdadeira. No caso dos pretos, Vieira ressalta que os trabalhos que sofrem, por brutais que sejam, não os devem impedir de adorar o Rosário. Em analogia com os salmos pro torcularibus, propõe que as orações do Rosário sejam feitas como cantos de alívio - worksongs, por assim dizer - durante a jornada extenuante de trabalho no engenho. O nascimento para a fé implica em que o gentio esteja consciente de que, mesmo cativo, experimenta a Graça que o trouxe ao seio da verdadeira religião. Eis como Vieira o diz em seu célebre sermão à Irmandade dos Pretos: “[...] deveis dar infinitas graças a Deus por vos ter dado conhecimento de si, e por vos ter tirado de vossas terras, onde vossos pais e vós vivíeis como gentios, e vos ter trazidos a esta, onde, instruídos na fé, vivais como cristãos, e vos salveis". ${ }^{24}$

Está nítida a questão do valor relativo do cativeiro frente ao bem absoluto da conversão: sem afirmar a existência de qualquer bondade intrínseca à escravidão, e sem retirar o sentido injusto dela, Vieira considera que a nova situação vivida pelo gentio, ao permitir que ingresse na religião cristã, ainda que na condição de cativo, é melhor, mesmo que mais sofrida, do que a sua vida anterior livre, mas ignorante de Cristo. Numa fórmula simples: o cativeiro tem valor negativo menor que o positivo da conversão. Para Vieira, apenas agora, escravizados injustamente, os gentios conheciam a verdadeira liberdade: aquela que, catolicamente, não se pode definir como ausência de subordinação temporal a um senhor e tampouco como autonomia da vontade própria, mas sim como exercício do arbítrio que reconhece e elege para si o bem de Cristo. A liberdade cristã, nesse sentido, traduz-se pelo conhecimento do bem que impede incorrer no mal. Vale dizer, é o pecado, e não o cativeiro temporal, que caracteriza a verdade última da escravidão. ${ }^{25} \mathrm{E}$ sem que Vieira chegue jamais a considerar a escravidão como necessidade natural da conversão - ao contrário, para ele, a escravidão é sempre um estorvo da eficácia - os escravos negros são sujeitos de uma eleição divina, que os habilita milagrosamente à salvação. $\mathrm{O}$ mesmo milagre se estende aos índios.

As duas virtudes cristãs que, juntas, podem desfazer o "laço diabólico" da escravidão são a "obediência" do escravo, em gratidão pela graça recebida da religião, e a "caridade" do senhor, para zelar pela alma do cativo. A junção virtuosa de ambas se pode traduzir pela virtude da "paciência", análoga à de Cristo, pois essa é a virtude essencial que se pede a ambos: ao cativo, para aceitar sem rebeldia os trabalhos exaustivos que semelham em tudo à via crucis; ao proprietário dele, para fazer jus à posição de senhorio, que tem almas à sua conta. Insisto: o conceito de liberdade, aí, não tem qualquer valor autônomo à esfera religiosa. A categoria substancial a definir a existência da liberdade é a 
adesão ao grêmio da igreja e o serviço da religião, não a independência liberal da vontade própria ou da ausência de superior hierárquico. O mesmo vale para a idéia de igualdade. O que a define é a referência ao corpo místico da Igreja, nunca a inexistência de hierarquia na Igreja ou no Reino, o que, de resto, seria iniquidade, uma vez que, considerados catolicamente, os homens são desiguais por natureza e a justiça está em manter a proporção relativa que ocupam no interior do organismo coletivo.

Vieira, portanto, está próximo de seus pares dos séculos XVI e XVII, não dos ilustrados e liberais dos seguintes. Os argumentos que levanta são afins, por exemplo, aos do jesuíta Luís de Molina, que defende que "a escravidão sob domínio cristão conduz ao bem espiritual dos escravos" e que é "um ato de caridade comprar a liberdade" deles "para que se tornem cristãos". ${ }^{26}$ Entretanto, tanto Vieira como Molina não duvidam que seria vantajoso trocar o penoso processo do cativeiro pela conversão advindo do puro zelo missionário.

Em resumo, aplica-se a Vieira o que já foi dito pelo bispo de Münster a propósito dos tratadistas católicos do período, a saber, que eles “jamais propugnaram por uma total igualdade de todos os povos e homens. É doutrina católica a desigualdade humana, em talentos naturais, em valores morais e em graça". ${ }^{27}$ O ponto em que os homens se igualam é apenas o de que "todo ser de rosto humano é um filho remido de Jesus Cristo", ${ }^{28} \mathrm{o}$ que significa que todos, por efeito natural da criação e pela graça de Cristo, são igualmente aptos para a salvação. "Salvar" índios e negros, definitivamente humanos, era o que pretendia o Padre Vieira e os seus companheiros de fé. A redução do gentio boçal a membro da Igreja hierárquica, com a finalidade política comum ao corpus mysticum do Estado cristão, era a melhor medida da liberdade e da igualdade a que podiam chegar.

III

Um terceiro aspecto a considerar na maneira do Padre Vieira conceber a escravidão indígena diz respeito ao papel missionário que atribui a Portugal. Mais do que concordar com o cronista espanhol Lopes de Gómara, que, cem anos antes, acreditava ser os descobrimentos o maior acontecimento desde a Criação, excetuada a Encarnação, Paixão e Morte do Cristo ${ }^{29}$ para Vieira, eles são figura de uma Criação verdadeiramente nova. E a novidade está em exigir o concurso de uma causa segunda na consumação da história salvífica do homem:

Quando Deus criou o mundo, diz o sagrado texto que a terra não se via porque estava escondida debaixo do elemento da água, e tudo escuro e coberto de trevas: Terra autem erat invisibilis - como leem os Setenta - et tenebrae erant super faciem abyssi. Então dividiu Deus as águas; e criou a luz e cessaram as trevas: Divisit aquas; facta est lux; appareat arida. Este foi o modo da primeira criação do mundo. E quem não vê que o mesmo observou Deus na segunda, por meio dos portugueses? ${ }^{30}$

A nova criação, na qual os portugueses são coautores da Providência, traz a luz da conversão que rompe as trevas da infidelidade, constituindo-se como 
fundamento e finalidade teológicos da ação dos europeus no Novo Mundo. A rigor, era o índio, e não as minas de ouro, que tocava descobrir e desentranhar - por isto, para Vieira, de maneira providencial, estas não se achavam em terras brasileiras. ${ }^{31}$ Reduzir à fé as nações indígenas era atualizar a conversão da gentilidade figurada nas Escrituras pela conversão dos reis magos, produzindo-se um segundo nascimento da Cristandade. Essa nova conversão funda, por sua vez, uma Nova Igreja, a única universal, apta a reparar os cismas recentes que arruinaram o Orbis Christianus. A ação missionária funcionava então como revitalização do grêmio da Igreja pela inclusão maciça de novos sócios, ignorantes das velhas querelas europeias que os dividiam. A alma do indígena em "tábua rasa" ou "papel em branco", metáfora recorrente aplicada ao índio, significava também uma imagem modelar de superação do passado recente buscada pela Igreja da Contrarreforma.

Para Vieira, com a fundação dessa Igreja nova, havia de cumprir-se o mandado de Cristo a Pedro para apascentar as nações de todo o mundo, de modo a "fazer de todas um só rebanho, que é a Igreja, debaixo de um só pastor, que é S. Pedro". ${ }^{32}$ Trata-se de um tipo de delegação animosa e apostólica muito distinta daquela que ocorre na guerra medieval contra os “infiéis". Dessa vez, “a verdadeira cavalaria" - como escreve Vieira, em carta de 1653, ao bispo do Japão - “é salvar almas”. ${ }^{33}$

Admitida a conversão como principal finalidade desta nova criação, Vieira postula a obrigação missionária como geral entre portugueses, e não exclusiva da Companhia de Jesus, ainda que a essa coubesse a função de estrela-guia do anúncio de Cristo aos gentios do Novo Mundo. E se todos os portugueses estão obrigados a pregar a palavra de Deus aos índios, há uma determinação religiosa entre senhor e escravo, vale dizer, a não ser como ocasião do zelo apostólico, a escravidão, naturalmente injusta, revela-se apenas um "laço diabólico". Superar a contradição das relações definidas pelo cativeiro implica a aceitação integral da obrigação missionária. As almas todas, diz Vieira, "devemos desejar que se salvem", mas aquelas dos escravos da casa estreitam as obrigações dos senhores: "ao menos não faltemos a estas tão desamparadas, às quais, por mais vizinhas, é mais devedora a nossa caridade". ${ }^{34}$

Pode-se dizer que a obrigação de ensino da doutrina aumenta com a escravidão, e também que o seu estado natural de injustiça não é anulado com o cumprimento da obrigação, mas as duas premissas articuladas definem um período histórico em que determinado meio imperfeito participa de um movimento perfectível da história. Para acentuar as relações complexas desse ajuste histórico, Vieira ressalta o desamparo em que se encontram os índios, e o crime contra a religião que cometem os moradores que, por cobiça, deixam de cuidar da doutrina e salvação das almas dos escravos a que estão obrigados. É assim que cria uma cena de terrível sublime no Sermão do Espírito Santo, pregado em 1657, em São Luís do Maranhão, quando os escravos ressuscitados reúnem-se 
para clamar por justiça contra o senhor que os levou a morrer na ignorância da fé. Em meio ao transe, Vieira atenua a culpa do escravo e anula a desculpa do senhor:

Certo que eu antes quisera dar conta pela sua parte que pela vossa. O escravo escusar-se-á com o seu senhor; mas o senhor, com quem se há de escusar? O escravo poder-se-á escusar com o seu pouco entendimento, com a sua ignorância: mas o senhor, com que se escusará? Com a sua muita cobiça? Com a sua muita cegueira? Com faltar à piedade? Com faltar à humanidade? Com faltar à cristandade? Com faltar à fé? ${ }^{35}$

A eloquência da condenação, entretanto, não visa a abolir a relação senhor-cativo, mas a impedir que se possa desobrigar da contrapartida da obrigação religiosa. É má leitura uma interpretação abolicionista da argumentação vieiriana: não se trata de extinguir a escravidão, mas de encontrar meio de conciliá-la com a missão apostólica no Mundo Novo; não se trata de considerá-la justa, pois priva o índio do que lhe é devido por Direito natural, mas de acreditar que maior é o bem da Graça, trazido pela religião, do que o mal temporal, temporário, do trabalho escravo; não se trata de apenas amenizar as dores do cativeiro com o unguento da doutrina, mas de postular que a religião repõe como caridade a liberdade de que foi privado o indígena. Daí que, falando a propósito da posse de escravos, Vieira conceda-os de bom grado: "Tende-os, cristãos, e tende muitos, mas tende-os de modo que eles ajudem a levar a vossa alma ao céu, e vós as suas". 36

$\mathrm{O}$ argumento da obrigação de facultar ao escravo o ingresso na Igreja completa-se com tomá-la como causa de condenação não apenas do senhor particular, mas da ruína da monarquia. O não cumprimento da missão apostólica devia ser entendido como ato herético, que ameaça a sobrevivência do Estado - definindo-se o caráter herético, por sua vez, como a pressuposição de que um pecado fosse necessário à conservação do Estado, como se costumava justificar a prática do cativeiro. Nesses termos, a posição de Vieira é antimaquiavélica, de acordo com a doutrina católica da Razão de Estado: "sobre os fundamentos da injustiça nenhuma cousa é segura nem permanente". ${ }^{37}$ A tirania, definida escolasticamente como correlata viciosa da monarquia prudente, também se caracteriza pelo abandono das almas a seu cuidado -, o que ameaça o corpo inteiro do reino e, em particular, a sustentação da coroa pelo rei esquecido de suas obrigações.

Em resumo: a missão, entendida como base de sustentação do Império português, toma-se como atualização histórica da Providência. Fracassar aí é perder tudo: corpo, cabeça e alma do Estado. Acertar é conduzir a história às alegrias do que Vieira imaginara como V Império do mundo, espécie de paraíso terreal, no qual cada um dos membros se reconhece como indivíduo e como membro da comunidade eclesial e política, expandida e reunificada, fazendo coincidir a bem-aventurança com os bens da fortuna. 
Isso aponta já para o quarto aspecto a ser examinado na questão da escravidão indígena em Vieira, qual seja o da estreita articulação semântica que produz entre as noções de conveniência e consciência, de tal modo que agir com justiça face aos índios significaria, igualmente, tratar com eficácia os negócios terrenos. É fundamental em Vieira esse tipo de argumentação que busca acomodar aspectos temporais e espirituais, evidenciando os frutos histórico-políticos advindos da correta semeadura ético-religiosa.

A propósito desse esforço de acomodação dos interesses espirituais e temporais, entretanto, há muitos equívocos a superar. Mais de uma vez se tem dito que a perspectiva vieiriana racional favorável à libertação dos escravos, entendida também como reconhecimento de uma suposta alteridade indígena, entra em confronto com as condições reais das práticas de exploração colonial e o induz a posições contraditórias, em que uma perspectiva progressista vê-se obrigada a concessões que a acabam contrariando. Essa forma de considerar o assunto do índio em Vieira busca ela própria conciliar dois paradigmas -, a saber, o catolicismo liberal, pós-ilustrado, e o socialismo de inspiração marxista -, ambos absolutamente estranhos aos termos válidos para Vieira e o século XVII.

Para deixar de lado a crítica óbvia do anacronismo e entrar a fundo na formulação do jesuíta, o principal é perceber que a acomodação entre consciência cristã e conveniência política é uma tópica global em Vieira, isto é, regula toda a aplicação de seus argumentos a qualquer assunto, e nem de longe está restrita a um confronto entre ideal religioso e condições externas das práticas coloniais. A formulação de seu projeto missionário nunca se dá em chave exclusivamente espiritual, ou de idealização pós-romântica, no sentido de que os bens da humana cristandade possam dispensar-se de responder às duras práticas terrenas. Ao contrário: os seus sermões apresentam-se sempre em vista de questões muito concretas, incluindo-se aí as injunções econômicas, em que pretendia intervir. É verdade que isso tendeu a chocar o espiritualismo burguês que o leu sempre espantado com a mistura de religião e negócios em seus sermões. Contudo, não há nada mais estrutural neles.

De um ponto de vista historicamente mais razoável, as condições práticas da colônia, ou da vida política enfim, são o lugar próprio em que Vieira dá forma final aos seus argumentos. Na chave teológica do período, o seu projeto missionário não pretende ser apenas espiritual, ou afinar-se por um diapasão idealista em que os bens da eternidade cristã estão propostos sem a circunscrição de práticas. Ver, em Vieira, implica antes atender às cegueiras da terra. O sentido básico dos sermões - retórico, em seu significado próprio, que visa a mover o seu auditório, agir sobre ele, para que esse aja em conformidade com sua pastoral -, obriga, desde o princípio, à consideração dos lugares comuns estabelecidos nas diferentes circunstâncias em questão. 
Mesmo a posição mais contrária aos interesses dos colonos e mais difícil de prevalecer - aparentemente, portanto, mais idealista -, é formulada por Vieira a partir de situações muito concretas. É a percepção aguda dos interesses em jogo que o leva a adotar posições de maior ou menor confrontação com os coloniais, o Conselho Ultramarino, ou o rei, e não apenas crenças ou ideais a priori, a salvo das circunstâncias. Vale dizer, o paradigma discursivo vieiriano assenta-se no caso e não na pura ideia anterior ou indiferente ao real. A conciliação dos mundos material e espiritual é o que há de mais apriorístico em seus sermões, e assenta-se na analogia tomista essencial entre os dois universos, sem que percam as suas diferenças de natureza, isto é, sem que o mundo temporal seja tomado apenas como decaído ou desviante em relação ao espiritual. No programa seiscentista de Vieira, a essência humana dual, matéria e espírito, que determina o ser, é termo irredutível de sua gramática. E se há algo constante no discurso vieiriano é a busca de acomodação analógica entre a natureza humana e a divina, entre a finalidade histórica e a providencial, que está na base da Igreja Militante e da ação missionária da Companhia de Jesus.

Para evidenciar a maneira como o Padre Vieira entende esta relação de conciliação entre a consciência cristã e as práticas temporais -, que responde catolicamente à "separação" maquiavélica entre o ético e o político -, basta observar as muitas propostas que faz aos moradores do Brasil, contrários à aplicação da lei de liberdade dos índios. Por exemplo, no Sermão da Primeira Dominga da Quaresma, de 1653, pregado em S. Luís, Vieira começa encarecendo o valor da alma, sem preço que a pague o bastante: "Se para segurar a consciência, e para salvar a alma, for necessário perder tudo, e ficar como um Jó, perca-se tudo". ${ }^{38}$ Entretanto, não crê que seja o caso para isso: "[...] bom ânimo, senhores meus, que não é necessário chegar a tanto nem a muito menos. Estudei o ponto com toda a diligência e com o afeto, e, seguindo as opiniões mais largas e mais favoráveis [...] - e lá segue ele a apresentar a solução que descobre, de modo que sempre se possa, "com muita pouca perda temporal", ainda "segurar as consciências de todos os moradores deste Estado". E isso significa que os moradores, mantendo os seus "muitos grandes interesses" possam ainda "melhorar suas conveniências para o futuro".

No caso das missões jesuíticas, a acomodação que propõe é resumidamente a seguinte: posse apenas de escravos voluntários, sendo os demais levados para as "aldeias d'el rei"; garantia de entradas frequentes ao sertão; resgate e cativeiro justo de índios "em corda", isto é, aprisionados e condenados à morte por tribo rival; manutenção do cativeiro de índios escravizados em "guerra justa"; julgamento de todos os cativeiros por uma Junta de que participariam Governador, ouvidor-geral dos índios, vigário do Maranhão ou Pará e prelados das quatro religiões atuantes na província; repartição pro rata, entre todos os moradores, dos cativos por justa causa; condução dos índios, cujo cativeiro não fosse confirmado pela Junta, para as aldeias, sendo que, durante seis meses, trabalhariam 
para a própria família, e durante os outros seis em casa de colonos, mediante pagamento de duas varas de algodão por mês.

Da aceitação da proposta, segundo Padre Vieira, decorreriam vários bens para os moradores: ficar "com as consciências seguras"; tirar de suas casas "esta maldição" de servir-se "com suor e com sangue injusto"; haver "muitos resgates, com que se tirarão muitos índios, que de outra maneira não os haverá"; e, por último, ter uma proposta "digna de ir às mãos de Sua Majestade" que a aprove e confirme, por proveitosa e justa. ${ }^{39} \mathrm{Ou}$ seja, trata-se de encontrar uma acomodação entre a salvação espiritual, ameaçada pelo pecado do cativeiro injusto dos índios, e a manutenção de certa prática do mesmo cativeiro, desde que agora regulada por disposições de justiça jurídica e teológica.

O mesmo propósito de ajustar as razões do Estado e da Religião manifesta-se nas dezenove medidas que, em carta de 1654, Vieira propõe a D. João IV. Interessa, no caso, menos relacioná-las do que observar como ele aplica a tópica da conveniência: "aqui não se trata só do justo" - escreve - "senão também do justificado". "Vale dizer: ao zelo espiritual e ético deve somar-se a conveniência temporal; ou de outra maneira ainda: a eficácia dos negócios necessariamente participa do zelo da fé.

A tópica da conveniência também se encontra em todos os seus discursos ao rei e aos grandes do reino. Em geral, apresenta-a como justificativa da necessidade de mudança de uma disposição qualquer sobre as missões, que a "experiência tem mostrado" insatisfatória ou inexequível, de modo a dar-se "remédio" eficaz, "mais conveniente e praticável", 41 à questão. Vieira também lança mão desse topos como prova da temperança e da boa-vontade de sua própria posição, em tudo disposta à pacificação dos portugueses do Brasil, enquanto esses, ao contrário, tomam decisões tão desleais em vista do bem comum do reino, como heréticas em relação à Igreja, fazendo do Maranhão e Pará "uma Rochela de Portugal". ${ }^{42}$

É sobretudo na armadilha desse último ponto que caem os analistas que julgam que Vieira cede de suas convicções diante das dificuldades da realidade colonial. Pois é exatamente essa a ideia que pretende demonstrar ao rei: a de sua própria tolerância e condescendência em contraste com a teimosia e a cobiça dos moradores. O topos da conciliação faz pensar que sempre esteve disposto a transigir e a encontrar uma solução comum para o assunto, e que furtar-se a ela é facciosismo e sem-razão da parte exclusiva dos moradores. Esclareço que não penso que Vieira esteja sendo falso. A sua disposição casuísta está sustentada na concepção teológico-política de que, havendo ou não resistência dos moradores ao projeto das missões, o bem comum da República é análogo ao projeto de salvação da comunidade religiosa. Isso equivale a crer que a verdade da consciência moral e da reta prática cristã não poderá se opor a uma acomodação que produza um desdobramento eficaz da história da monarquia cristã. Ou seja, para dizê-lo numa fórmula simples: deixar de conciliar ou acomodar é abdicar do jesuiticamente inabdicável: a eficácia histórica da pastoral missionária. 
Assim, quando Vieira anuncia publicamente o mea culpa da muita conciliação que tentara de suas posições com as dos moradores, ele constrói de fato uma grave acusação, mas não para si mesmo. Ficam acusados, isso sim, os que, apesar de tanta demonstração de boa vontade e desejo de concórdia por parte dos jesuítas, ainda permanecem teimosamente apegados à sua falta de piedade, à sua cobiça invencível, à sua prática facciosa indiferente a Deus e às leis do reino. O que parece "remorso" é acusação de que nada basta para contentar o vício dos falsos cristãos do Maranhão. A culpa dele, Vieira, é tão somente a do excesso de zelo e de desejo de concórdia, insuficientes ainda assim para comover aos maus portugueses da colônia. Ou seja, quanto mais contundente a afetação do mea culpa de sua própria concessão, tanto mais torna monstruosa a facção dos adversários.

E se algum arrependimento crível há aí não é o de esforçar-se por conciliar as diferenças das posições no jogo das práticas, mesmo à custa da limitação das liberdades indígenas, mas o de tê-lo feito sem lograr fruto, isto é, sem chegar a um acordo efetivo com os moradores. Se há um erro aventado aí é o da estratégia equivocada da acomodação, não o da má consciência por havê-la proposto. A sua consciência está bem segura, e mais ainda por ter tentado tudo, até arriscar-se a si mesma, em nome do mais alto valor da concórdia no rebanho de Cristo e no corpo do Estado.

Ao redimensionar a questão dessa maneira, gostaria de deixar bem claro que a este trabalho não interessa demonstrar o grau de imoralidade ou falsa consciência seja de Vieira, da Segunda escolástica ou da Igreja colonial. Bem ao contrário, a imagem de orador de Vieira surge aqui como a de um perfeito exemplo da moralidade eclesiástica, tal como se possa supor plausível no século XVII. Pretender a condenação do jesuíta (ou desculpar-se por ele), parece tão anacrônico e revisionista quanto reclamar para ele, que já não precisa de nós, o louvor do avanço ilustrado. Fabricar um verossímil de suas práticas e letras, conhecer as razões que as punham em funcionamento, os lugares comuns que thes dava sentido e consistência, eis tudo o que me interessa fazer.

O quinto e último aspecto do tema da escravização do índio a considerar aqui diz respeito ao método que o Padre Vieira defende para a redução dos brasis. É certo, para começar, que ele condiciona o êxito das missões indígenas no Brasil a um acontecimento fundamental: o monopólio da Companhia de Jesus na condução dos negócios dos índios. Isso implica, primeiro, estabelecimento de prerrogativas frente às demais ordens religiosas, e, segundo, em jurisdição independente das aldeias, sem interferência do governo da província, a não ser em tempo de guerra, sob condições restritas. Para demonstrar a necessidade de o governo português atender ao primeiro ponto, os argumentos que emprega com mais freqüência são o da falta de letras dos índios e o do pouco zelo das outras religiões, ambos já empregados por Nóbrega. Assim, ao escrever a D. 
João IV, em 1655, sobre a dificuldade que os padres da Companhia estavam encontrando para converter os tupinambás, atribui-a sobretudo à presença de maus religiosos entre eles.

Já em relação ao ponto da jurisdição independente das missões, o argumento básico que Vieira utiliza é o da experiência: esta demonstra que a submissão das “aldeias d'el rei” ao governo da Província deixa os índios à mercê de uma cobiça que explora os seus corpos até a morte, abandonando qualquer assistência as suas almas. Como forma de impedir os crimes, Vieira exige para a Companhia o governo temporal e espiritual das reduções, de que julga depender êxito de toda a nova vocação da gentilidade. Aos jesuítas cabem as duas chaves, ou duplo gládio, das missões:

Por isso é necessário que as chaves sejam duas, e que ambas estejam na mesma mão. Uma com que Pedro possa abrir as portas do céu, e outra com que possa aferrolhar as portas do inferno; uma com que possa levar os gentios a Cristo, e outra com que os possa defender do demônio, e seus ministros. E toda a teima do mesmo demônio e do mesmo inferno, é que estas chaves e estes poderes se dividam, e que estejam em diferentes mãos. ${ }^{43}$

A conclusão é: “[...] Necessário é, logo, não só para o espiritual, senão também para o temporal das conquistas, que os mesmos que edificam aquelas novas igrejas, assim como têm o zelo e a arte para as edificar, tenham juntamente o poder para as defender". ${ }^{44}$ Os jesuítas são os "edificadores" das "novas igrejas" e, como os trabalhadores que construíram o Templo sob a permanente ameaça dos samaritanos ( 2 Esdr 4,17 ), necessitam ter numa mão a espada, e a obra na outra: "[...] e se os mesmos trabalhadores não tiverem espada com que defendam o que trabalham, não só parará, como está parada a obra, mas perder-se-á, como se vai perdendo, quanto com trabalho se tem obrado". ${ }^{45}$

O Padre Vieira antecipa a réplica dos adversários de que "a espada é instrumento profano e leigo, e não diz bem em mãos sagradas", ${ }^{46}$ construindo uma analogia de proporção entre o atual governador da província do Maranhão e Herodes; entre Belém do Pará e Belém de Judá; entre o suplício dos inocentes e a escravidão dos gentios, tudo resultando no modelo centralizador de ação adotado por S. Paulo como figura da Companhia de Jesus:

Por que traz Paulo em uma mão o livro, noutra a espada? Porque Paulo entre todos os outros apóstolos foi o vaso de eleição escolhido particularmente por Cristo para preparador dos gentios: Vas electionis est mihi iste, ut portet nomen meun coram gentibus - e quem tem por ofício a pregação e conversão dos gentios há de ter o livro em uma mão e a espada na outra: o livro para os doutrinar, a espada para os defender. E se esta espada se tirar da mão de Paulo, e se meter na mão de Herodes, que sucederá? Nadará toda a Belém em sangue inocente, e isso é o que vemos. ${ }^{47}$

Em outra analogia, quem figura a Companhia é o "pastor", que não pode esquecer a dupla função de seu cajado: 
[...] respondei-me: Quem tem obrigação de apascentar as ovelhas? O pastor. E quem tem obrigação de defender as mesmas ovelhas dos lobos? $\mathrm{O}$ pastor também. Logo o mesmo pastor, que tem o cuidado de as apascentar, há de ter, também, o poder de as defender. Esse é o ofício do pastor, e esse o exercício do cajado. Lançar o cajado à ovelha para a encaminhar, e terçá-lo contra o lobo para o defender. E vós quereis que este poder esteja em uns, e aquele cuidado em outros? Não seja isso conselho de lobos! ${ }^{48}$

A consciência dessa dupla função, que não se exime da ação temporal para fazer vingar a saúde espiritual do rebanho, distingue o "pastor" do "mercenário", pois esse, "quando vê vir o lobo para o rebanho, foge, e deixa-o roubar e comer as ovelhas". E a tais argumentos, que dão publicidade às grandes dificuldades do negócio da salvação das almas, Vieira acrescenta outras, como a falta de padres, igrejas, recursos etc., que sempre preencheram a petitio das cartas jesuíticas do Brasil, não apenas as dele.

Para abreviar o relato, pode-se dizer que os discursos vieirianos, lidos como partes de uma prática suasória, historicamente delimitada, aplicam os lugares retóricos estabelecidos pelos escolásticos do século XVI de forma bem definida: eles se concentram nos argumentos favoráveis à criação das condições práticas que julgava indispensáveis para a finalidade da conquista, traduzidas pelo privilégio da Companhia no governo independente nas missões e na prerrogativa temporal e espiritual dos jesuítas na condução do índio ao corpo místico do Estado. Além disso, é preciso lembrar que o índio, em Vieira, é parte de um projeto universal de avanço do exército dos novos conversos, sob o influxo do rei de Portugal e da Igreja militante, ambos concebidos à imagem da Companhia de Jesus.

Enfim, se puder dar remate um pouco extemporâneo a este esboço rígido de retrato da escravidão do índio em Vieira, lembro que, para ele, se as missões são Providência divina, com igual direito o é a própria força da sua oratória que responde a ela. Como que a observar de fora o milagre da intervenção de Cristo por meio de sua palavra, o Padre Vieira comenta o seguinte ao Provincial do Brasil sobre o efeito do Sermão da Primeira Dominga da Quaresma, de 1653, que pregara em S. Luís:

E quando todos estes respeitos não tinham alguma valia, e os ânimos dos homens estavam tão alheios de nós, e tão odiada com eles nossa vinda, uma vez que subi ao púlpito, e preguei o evangelho de Cristo, foi tanta a sua eficácia e autoridade, e tal o respeito que nós concebíamos com ela, que mudados em um momento os juízos e vontades de tantos homens, e tão interessados, anoitecemos amados, respeitados, louvados e seguidos dos mesmos que, na manhã do mesmo dia, nos aborreciam, nos murmuravam, nos perseguiam, e tanto a seu pesar nos tinham entre si. Oh! força das forças de Deus! Oh! portentosa providência do Altíssimo! Quam incomprehensibilia sunt judicia Dei! ${ }^{49}$ 
Mas não é mesmo extraordinário pensar, hoje, o poder que o jesuíta atribui à palavra e ao argumento, ainda quando lançados em meio iletrado e venal? Embora surpreendentemente cada vez mais se fale de Deus, e em nome de Deus, nada parece mais morto e enterrado do que o Deus intelectual e culto do Padre Vieira.

\section{Notas}

1 In: Relecciones Teologicas; Madrid: Ed. de Luis Getino, 1933-1934, v.II, p.368.

2 Madrid, Annuario de la Asociación Francisco de Vitoria, 1931, v.II, p.63.

3 De Indis, op. cit., II, p.370

4 Refiro os Sermões pela edição paulista, de 1957, em 24 volumes, da Edameris. Citação à p.184 do volume XXI.

5 Idem, p. 187.

6 Cartas, op cit., I, p.467-8.

7 Idem, p. 468.

8 Cartas, I, p.68.

9 Política, Livro Primeiro, especialmente o capítulo 5 (na edição das Obras, da Aguilar madrilenha, ocupa as páginas 684-7). Sobre a utilização do texto aristotélico nas disputas sobre o estatuto dos índios, há trabalhos clássicos como o de Lewis Hanke (Aristotle and the American Indians. Bloomington, Indiana Univ. Press, 1970; La humanidad es una, México, FCE, 1985, 2a. ed.) e Silvio Zavala (Filosofia de la Conquista, México, FCE, la. reimpr. da 3a. ed., 1984). O Tratado sobre las justas causas de la guerra contra los indios, de Sepúlveda, tem uma boa edição moderna da FCE, com estudo de Manuel Garcia-Pelayo. Li-a na 2a. reimpr., de 1987. Uma comparação lado a lado dos textos de Aristóteles e Sepúlveda é feita por Pelayo à p.21ss.

10 Sermões, VII, p.212.

11 Sermões, IX, p.248.

12 Colonização e Evangelho - Ética da Colonização Espanhola no Século de Ouro, RJ, Presença, 1977, 2.ed.. Citação à p.48.

13 Ibidem.

14 Ibidem.

15 Conferir Höffner, op. cit., p.98.

16 Ver Lewis Hanke em La humanidad es una, México, FCE, 1985, p.28ss.

17 Cartas, I, p.398.

18 Ibidem, I, p.400.

19 Nóbrega, Manuel da: Diálogo sobve a Conversão do Gentio, ed. de Mecenas Dourado. Rio de Janeiro: Ediouro, s. d. Citação à p.118.

20 Cartas, I, p.394.

21 A propósito, para que se evite uma leitura "intelectualista" das motivações que conduziram aos esforços mais decididos de balizamento ético das Conquistas, ver sobretudo a terceira parte do já citado livro de Höffner: p.177ss. 
22 Sobre o movimento curialista, ver Höffner, J.: op. cit., especialmente a primeira parte de seu trabalho, dedicada ao estudo do Orbis Christianus (p.17ss).

23 Cartas, I, p. 352: ao Provincial do Brasil, 1653.

24 Sermões, IX, p.250.

25 Sobre a noção de "liberdade" no cristianismo em sua linhagem tomista, ver Gilson, Étienne: L’Esprit de la Philosophie Médiévale. Paris: Vrin, 1983 (2.ed., 4a. tiragem). Consultar p.284ss.

26 Apud Höffner, op. cit., p.346.

27 Ibidem, p.376.

28 Ibidem.

29 Primera parte de la historia general de las Indias. Madrid: Biblioteca de Autores Españoles (v.22), 1894. À p.156 encontra-se a comparação superlativa.

30 Sermões, VII, p.323.

31 Sermão da Primeira Oitava da Páscoa, de 1656, v.VII, op. cit., p.219.

32 Sermão do Espírito Santo, V, op. cit., p.213.

33 Cartas, I, p.300.

34 Sermão da Primeira Oitava da Páscoa, op. cit., VII, p.222.

35 Sermão do Espírito Santo, op. cit., p.252-3.

36 Ibidem, p. 255.

37 Cartas, p.469.

38 Sermões, XXI, op. cit., p.193.

39 Sermão da Primeira Dominga da Quaresma, XXI, p.196-7.

40 Cartas, I, p.439.

41 Cartas, I, p.309.

42 Cartas, I, p.422.

43 Sermões, VII, p.357.

44 Ibidem.

45 Ibidem, p.358.

46 Ibidem.

47 Ibidem, p.358-9.

48 Ibidem, p.359.

49 Cartas, I, op. cit. p.342.

\section{Referências}

ARISTÓTELES. Política, Livro Primeiro. In: - Obras. Madrid: Aguilar, s. d.

GÓMARA, L. de. Primera parte de la historia general de las Indias. Madrid: Biblioteca de Autores Españoles, 1894. v.22.

HANKE, L. Aristotle and the American Indians. Bloomington: Indiana Univ. Press, 1970 . 
HANKE, L. La humanidad es una. 2.ed. México: FCE, 1985.

HÖFFNER, J. Colonização e Evangelho - Ética da Colonização Espanhola no Século de Ouro. 2.ed. Rio de Janeiro: Presença, 1977.

NÓBREGA, M. da. Diálogo sobre a Conversão do Gentio. Ed. de Mecenas Dourado. Rio de Janeiro: Ediouro, s. d.

SEPULVEDA. O Tratado sobre las justas causas de la guerra contra los indios. México: FCE, 1987.

VIEIRA, A. Sermões. São Paulo: Edameris, 1957. 24v.

VITORIA, F. de. Annuario de la Asociación Francisco de Vitoria. Madrid: s. n., 1931; v.II, p.63.

. De Indis. In: . Relecciones Teologicas. Madrid: Ed. de Luis Getino, 19331934. v.II, p.368.

ZAVALA, S. Filosofia de la Conquista. 3.ed. México: FCE, 1984.

RESUMO - A contribuição agrupa os diferentes estudos desenvolvidos pelo autor sobre a forma de Padre Vieira entender a escravidão, organizados em cinco tópicos-chave, a saber: a adesão aos termos da Segunda Escolástica; o processo de incorporação do indígena ao corpo místico do Estado; os termos usados pelas autoridades portuguesas para definir a missão atribuída a Portugal no Novo Mundo; a natureza indissolúvel do nexo entre conveniência e consciência suposto no chamado antimaquiavelismo; e, por fim, as práticas de conversão adotadas pelos jesuítas no Brasil.

Palavras Chaves: Padre Antonio Vieira, Sermões, Escravidão indígena, Missões jesuíticas.

ABSTRACT - This contribution groups different studies developed by the author on how Father Antonio Vieira understood slavery, and organizes them into five key topics: the adherence to the terms of the Second Scholasticism, the process of incorporating indigenous peoples to the State's mystical body, the terms used by Portuguese authorities to define the mission assigned to Portugal in the New World, the indissoluble nature of the nexus between convenience and consciousness in the so-called Anti-Machiavellism, and the conversion practices adopted by the Jesuits in Brazil.

KEYWORDS: Father Antonio Vieira, Sermons, Enslavement of Native Americans, Jesuit reductions.

Alcir Pécora é professor titular da área de Teoria Literária na Unicamp e membro da Academia Ambrosiana, seção Borromaica. É autor de vários ensaios sobre o Padre Vieira, e outros escritores do século XVII. É editor literário das obras de Hilda Hilst, Roberto Piva e Plínio Marcos. Atualmente é coordenador do Instituto de Estudos Avançados (IdEA), da Unicamp. @ - Alcirpecora@gmail.com / https://orcid.org/0000-0003-3366-4746

I Instituto de Estudos da Linguagem, Universidade Estadual de Campinas, Campinas, São Paulo, Brasil.

Recebido em 31.5.2019 e aceito em 28.6.2019. 